\title{
Growth of tomato plants in a split-root system as affected by various boron levels in the nutrient solution
}

\author{
A. Cerdá ${ }^{*}$ and J. P. N. L. Roorda van Eysinga ${ }^{2}$ \\ 1 Rijksuniversiteit Utrecht, The Netherlands, stationed at Proefstation voor \\ Tuinbouw onder Glas, Naaldwijk, the Netherlands \\ 2 Instituut voor Bodemvruchtbaarheid, Haren-Gr. The Netherlands, stationed \\ at Proefstation voor Tuinbouw onder Glas, Naaldwijk, the Netherlands
}

Accepted: 14 June 1981

Key-words: nutritional disorders, boron nutrition, split-root, lateral movement.

\section{Summary}

In a split-root system, growth characteristics and boron translocation were investigated in tomato plants grown in culture solutions with different $B$ levels.

Slight B toxicity was associated with $324 \mu \mathrm{mol} \mathrm{B}$ per litre $(=3.5 \mathrm{mg} / \mathrm{litre})$ in the solution, while $3240 \mu \mathrm{mol}$ ( $=35 \mathrm{mg} /$ litre $)$ produced clear symptoms. B deficiency was only observed when B was omitted from both halves of the system. A boron level of $3240 \mu \mathrm{mol}$ reduced weight of tops and roots in proportion to the parts, one or both, to which it was applied. Weight of tops, but not of roots was reduced when boron was omitted from both parts of the system. There were no significant differences in growth between plants which received $32 \mu \mathrm{mol} \mathrm{B}$ per litre in one part of the system, in combination with 0,32 of $324 \mu \mathrm{mol} \mathrm{B}$ in the other part.

$\mathrm{B}$ contents were higher in the leaves of the side of the plant corresponding to the roots growing under high-B conditions. B content of leaves on the low-B side increased when the concentration in the high-B side was increased. This indicates a lateral movement of $B$.

Roots which received no $B$ in either side of the system absorbed less nutrients, especially phosphate and potassium.

\section{Introduction}

Boron is an essential nutrient for the growth of higher plants. For most plant species cultivated, the proper $B$ level is difficult to attain because the range be-

* Present address: Centro de Edafologia y Biologia Aplicada del Segura, Apdo 195, Murcia, Spain. This study and the residence of Dr Antonio Cerdá was made possible by an interchange fellowship between the Rijksuniversiteit of Utrecht and the Consejo Superior de Investigaciones Cientificas, Madrid, Spain. 
tween B deficiency and B toxicity is very narrow (Reisenauer et al., 1973). The problem is especially complicated when irrigation water with a high or a low content is used in a system which wets the soil locally, as in the case in many glasshouses. Consequently a part of the root system may be exposed to low $\mathrm{B}$ concentrations and another part to normal or even high B levels.

Since Eaton's classical paper was published (1944), much work on the effects of $B$ on a large number of cultivated crops has been reported, which was reviewed by Gupta (1979). However, data are lacking as to whether a plant can grow in a medium in which a part of its root system is exposed to B concentrations that are too low or too high for normal growth. Bingham \& Garber (1970) reported the results of applying different $B$ concentrations to the top, middle and bottom portions of a corn root system, as will be discussed later.

The present study was designed to evaluate the effect of boron on growth characteristics, root development, and B uptake in tomato plants grown in a splitroot system, in which different $B$ levels were given to each half of the root system.

\section{Materials and methods}

Tomato (Lycoperscicon esculentum Mill, cv. Moneydor) seeds germinated in sand. When the plants were about $5 \mathrm{~cm}$ high, they were transferred (on 2 May 1980) to cubic rock-wool blocks of $7.5 \mathrm{~cm}$, of which the sides were covered with black plastic foil. The plants were left to grow until the roots reached the bottom of the rock-wool block. During this period the plants were irrigated daily, alternately, with demineralized water or a nutrient solution. This solution contained $10.5 \mathrm{mmol} \mathrm{NO}_{3}^{-}, 1.5 \mathrm{mmol} \mathrm{H}_{2} \mathrm{PO}_{4}^{-}, 2.75 \mathrm{mmol} \mathrm{SO}_{4}{ }^{2-}, 0.5 \mathrm{mmol} \mathrm{NH}_{4}{ }^{+}, 7.5$ $\mathrm{mmol} \mathrm{K}^{+}, 3.75 \mathrm{mmol} \mathrm{Ca}{ }^{2+}, 1 \mathrm{mmol} \mathrm{Mg}{ }^{2+}, 32 \mu \mathrm{mol} \mathrm{B}, 9 \mu \mathrm{mol} \mathrm{Fe}, 18 \mu \mathrm{mol} \mathrm{Mn}, 8$ $\mu \mathrm{mol} \mathrm{Zn}, 0.3 \mu \mathrm{mol} \mathrm{Cu}$ and $0.5 \mu \mathrm{mol} \mathrm{Mo} \mathrm{per} \mathrm{litre.} \mathrm{The} \mathrm{pH}$ was 5.6 and the electrical conductivity (EC) $1.8 \mathrm{mS} / \mathrm{cm}$ at $25^{\circ} \mathrm{C}$.

On 21 May, each plant in the rock-wool block was placed on the upper edges astride two 2-litre plastic pots filled with the nutrient solution without boron. Half the root system of each plant was placed in each pot (see Fig. 1). After 10 days, when the plants had developed plenty of roots in the solutions and had reached first-bloom stage, the differential treatments were started by adding to the nutrient solution (without boron) $\mathrm{Na}_{2} \mathrm{~B}_{4} \mathrm{O}_{7} \cdot 10 \mathrm{H}_{2} \mathrm{O}$ in quantities of $0,32,324$ and $3238 \mu \mathrm{mol}$ B per litre $(=0,0.35,3.5$ or $35 \mathrm{mg} /$ litre $\mathrm{B})$. The two halves of the root system were grown in all combinations of these four levels, giving 10 treatments, being replicated three times (Table 1). The nutrient solutions in each pot were changed weekly and, if necessary, supplemented every day. $\mathrm{pH}$ was maintained between 5.5 and 6.5 .

At the conclusion of the experiment, solution samples were collected from each pot and analysed for all nutrients. 


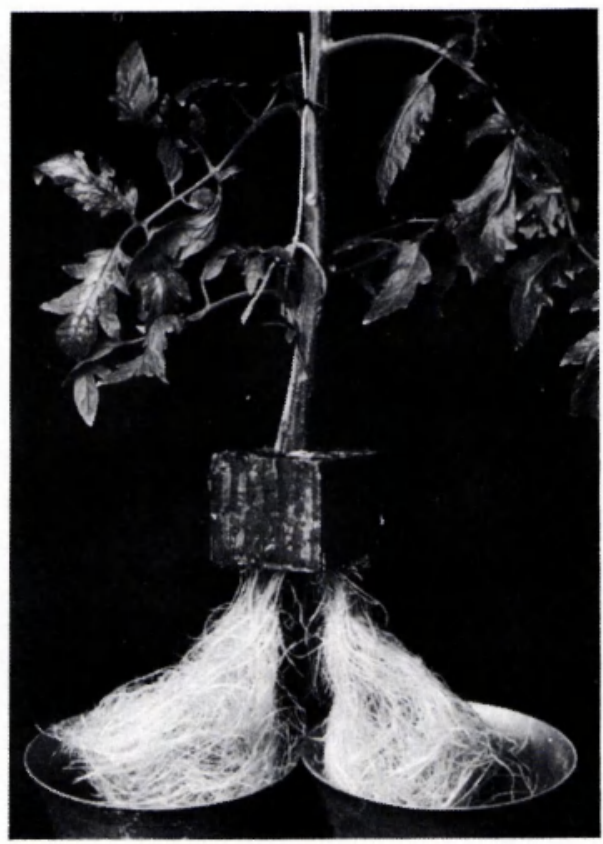

Fig. 1. Tomato split-root system.

On 24 June, when the third cluster was in bloom and the plants showed clear symptoms of B deficiency or B toxicity, the experiment was terminated. The plants were harvested and divided into tops and roots. Fresh and dry weights of the tops and dry weight of the roots were determined. At this time, leaf samples of the middle section of the plants were collected separately from either side, corresponding to each part of the split-root system. Another sample included the rest of the plant (leaves, stem and fruits). Samples were taken from each half of the root system. This provided five samples from each plant. The samples were dried at $70^{\circ} \mathrm{C}$, ground, and analyzed for $\mathrm{B}, \mathrm{Na}, \mathrm{K}, \mathrm{Ca}, \mathrm{Mg}, \mathrm{P}, \mathrm{Fe}, \mathrm{Mn}$ and $\mathrm{Zn}$. Only top and root weights were statistically analysed.

\section{Results and discussion}

\section{Nutritional disorders}

Four days after starting the treatments, plants with the complete or half of the root system in the solution containing $3238 \mu \mathrm{mol} \mathrm{B} /$ litre showed clear symptoms of $B$ toxicity characterized by necrotic spots on the margins of old and young leaves and in the interveinal tissue of old leaves. In the plants with only half of the root system in $3238 \mu \mathrm{mol} \mathrm{B} /$ litre the symptoms appeared first on that side; after 10-12 days they had extended to the entire plant. Leaf abscission and flower 


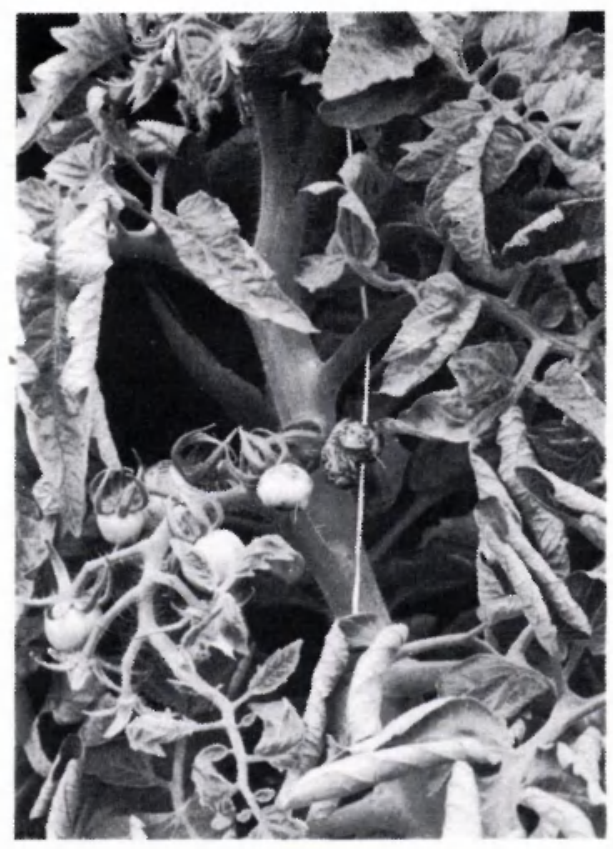

Fig. 2. Unripe tomato fruits showing B deficiency symptoms.

abortion were only observed in those plants with the whole root system in 3238 $\mu \mathrm{mol} \mathrm{B} /$ litre. Plants growing in $324 \mu \mathrm{mol} \mathrm{B} /$ litre in one compartment showed only slight symptoms of toxicity on the margins of the older leaves.

After 14 days, B deficiency symptoms were first observed in the fruits of plants growing in the solution without boron. These symptoms were pericarp deformation, brown spots and cracks in the skin, and the appearance of an opening in the fruit at the growing point (see Fig. 2). Later, the top leaves turned yellow and the growing point died. Lateral shoots developed. which gave these plants a bushy appearance. The roots of plants growing without boron in both parts were darker and thicker than those from other treatments. No B deficiency symptoms were observed when boron was applied to half of the root system only. Spurr (1957) pointed out that B deficiency in celery resulted in markedly thinner collenchyma cell walls. It is possible that the skin cracks and open fruits observed in this experiment are due to the presence of thin-walled collenchyma cells. Maynard et al. (1959) gave the same explanation for the disorder in tomato fruits, which they called open locule.

\section{Plant growth}

Growth in terms of dry and fresh weights of the whole tops of plants (leaves, shoots, and fruits) and dry weights of each half of the root system is given in Table 1 . The highest dry weights of tops were obtained when half of the root system 
Table 1. Weight of tops and roots of tomato plants as affected by different boron levels in a splitroot system.

\begin{tabular}{|c|c|c|c|c|c|}
\hline \multicolumn{2}{|c|}{ Treatment } & \multicolumn{2}{|l|}{ Top (g/plant) } & \multicolumn{2}{|c|}{ Root dry weight (g/plant) } \\
\hline code & $\begin{array}{l}\text { B level in each } \\
\text { half of the root } \\
\text { system ( } \mu \mathrm{mol} / \text { litre })\end{array}$ & fresh weight & dry weight & $\begin{array}{l}\text { each half of } \\
\text { root system }\end{array}$ & $\begin{array}{l}\text { total } \\
\text { root system }\end{array}$ \\
\hline $\mathrm{T}-1$ & $\begin{array}{l}0 \\
0\end{array}$ & 625 & 77.8 & $\begin{array}{l}3.6 \\
3.5\end{array}$ & 7.2 \\
\hline $\mathrm{T}-2$ & $\begin{array}{r}0 \\
32\end{array}$ & 883 & 97.9 & $\begin{array}{l}2.2 \\
3.4\end{array}$ & 5.7 \\
\hline $\mathrm{T}-3$ & $\begin{array}{r}0 \\
324\end{array}$ & 868 & 94.9 & $\begin{array}{l}3.1 \\
3.5\end{array}$ & 6.7 \\
\hline $\mathrm{T}-4$ & $\begin{array}{r}0 \\
3238\end{array}$ & 679 & 72.8 & $\begin{array}{l}2.1 \\
1.9\end{array}$ & 4.0 \\
\hline $\mathrm{T}-5$ & $\begin{array}{l}32 \\
32\end{array}$ & 908 & 97.8 & $\begin{array}{l}3.1 \\
3.4\end{array}$ & 6.5 \\
\hline$T-6$ & $\begin{array}{r}32 \\
324\end{array}$ & 905 & 97.2 & $\begin{array}{l}2.9 \\
3.4\end{array}$ & 6.3 \\
\hline$T-7$ & $\begin{array}{r}32 \\
3238\end{array}$ & 700 & 74.9 & $\begin{array}{l}2.1 \\
1.8\end{array}$ & 3.9 \\
\hline $\mathrm{T}-8$ & $\begin{array}{l}324 \\
324\end{array}$ & 888 & 94.6 & $\begin{array}{l}3.1 \\
2.8\end{array}$ & 5.9 \\
\hline T-9 & $\begin{array}{r}324 \\
3238\end{array}$ & 659 & 69.7 & $\begin{array}{l}2.5 \\
1.5\end{array}$ & 4.1 \\
\hline$T-10$ & $\begin{array}{l}3238 \\
3238\end{array}$ & 519 & 56.3 & $\begin{array}{l}1.3 \\
1.1\end{array}$ & 2.6 \\
\hline \multicolumn{6}{|c|}{$\begin{array}{l}\text { A nalysis of variance } \\
\text { (least significant difference } \\
\text { Tukey's multiple range }\end{array}$} \\
\hline $\begin{array}{l}\text { test) } \\
\text { coeffic }\end{array}$ & cient of variation & $\begin{array}{r}162^{* *} \\
5.9\end{array}$ & $\begin{array}{c}14.5^{* *} \\
4.9\end{array}$ & & $\begin{array}{l}1.9^{* *} \\
10.0\end{array}$ \\
\hline
\end{tabular}

** $\mathrm{P}<0.01$.

grew in a solution containing 32 or $324 \mu \mathrm{mol} \mathrm{B} /$ litre, with the other half in 0,32 or $324 \mu \mathrm{mol} \mathrm{B} /$ litre. These five yields were not significantly different, but compared with them, dry weights of tops were significantly lower'at a level of 3238 $\mu \mathrm{mol} \mathrm{B} /$ litre in one compartment. Yield reduction was greater when $3238 \mu \mathrm{mol}$ was present in both parts $(45 \%)$ than when this was the case in only one part ( $25 \%)$. These results clearly demonstrate that the yield reduction depended on both B level and quantity or roots exposed to that level. This is in agreement with the results of Bingham \& Garber (1970), who reported that the degree of injury in sweet corn was a function of the vertical portion of the root system exposed to toxic B levels. On the other hand, adequate B levels (32 or $324 \mu \mathrm{mol}$. $B$ /litre) given only to half of the root system met the B requirement of the entire plant. The trend in fresh weight of tops was similar to that of dry weight. 
Table 2. Composition of the nutrient solutions* in the pots two days after having been changed (mean of three determinations).

\begin{tabular}{|c|c|c|c|c|c|c|c|c|c|}
\hline \multicolumn{2}{|c|}{ Treatment } & \multirow[t]{2}{*}{ B } & \multirow[t]{2}{*}{$\mathbf{P}$} & \multirow[t]{2}{*}{$\mathbf{K}$} & \multirow[t]{2}{*}{$\mathrm{Ca}$} & \multirow[t]{2}{*}{$\mathrm{Mg}$} & \multirow[t]{2}{*}{$\mathrm{NO}_{3}$} & \multirow[t]{2}{*}{$\mathrm{SO}_{4}$} & \multirow{2}{*}{$\begin{array}{l}\mathrm{EC} \\
\left(\mathrm{mS} / \mathrm{cm} ; 25^{\circ} \mathrm{C}\right)\end{array}$} \\
\hline code & $\begin{array}{l}\text { B level in each } \\
\text { half of the root } \\
\text { system ( } \mu \mathrm{mol} / \text { litre) }\end{array}$ & & & & & & & & \\
\hline \multirow{2}{*}{$T-1$} & 0 & 0.02 & 0.69 & 4.3 & 1.6 & 0.4 & 2.7 & 1.6 & 0.9 \\
\hline & 0 & 0.01 & 0.72 & 4.2 & 1.6 & 0.5 & 2.5 & 1.6 & 0.8 \\
\hline \multirow{2}{*}{$\mathrm{T}-2$} & 0 & 0.01 & 0.59 & 3.2 & 1.4 & 0.5 & 1.9 & 1.2 & 0.7 \\
\hline & 32 & 0.01 & 0.17 & 1.8 & 0.7 & 0.2 & 1.1 & 1.0 & 0.5 \\
\hline \multirow{2}{*}{$\mathrm{T}-3$} & 0 & 0.02 & 0.28 & 2.2 & 0.6 & 0.2 & 0.2 & 1.0 & 0.5 \\
\hline & 324 & 0.27 & 0.17 & 1.8 & 0.6 & 0.2 & 0.1 & 1.0 & 0.4 \\
\hline \multirow{2}{*}{$T-4$} & 0 & 0.28 & 0.49 & 4.4 & 1.6 & 0.7 & 4.6 & 1.6 & 1.0 \\
\hline & 3238 & 2.75 & 0.24 & 4.2 & 1.2 & 0.4 & 4.8 & 1.4 & 1.0 \\
\hline \multirow{2}{*}{ T-5 } & 32 & 0.01 & 0.24 & 1.4 & 0.7 & 0.3 & 0.1 & 1.1 & 0.5 \\
\hline & 32 & 0.02 & 0.40 & 2.0 & 1.0 & 0.4 & 0.0 & 1.2 & 0.6 \\
\hline \multirow{2}{*}{ T-6 } & 32 & 0.07 & 0.18 & 1.3 & 0.7 & 0.2 & 0.1 & 0.9 & 0.4 \\
\hline & 324 & 0.31 & 0.35 & 2.6 & 1.0 & 0.4 & 0.1 & 1.4 & 0.6 \\
\hline \multirow{2}{*}{ T-7 } & 32 & 0.60 & 0.32 & 2.9 & 1.3 & 0.4 & 2.4 & 1.5 & 0.7 \\
\hline & 3238 & 2.63 & 0.22 & 4.2 & 1.3 & 0.4 & 4.2 & 1.7 & 0.9 \\
\hline \multirow{2}{*}{ T-8 } & 324 & 0.35 & 0.11 & 2.4 & 0.7 & 0.2 & 1.2 & 1.5 & 0.6 \\
\hline & 324 & 0.30 & 0.25 & 2.1 & 0.8 & 0.3 & 0.5 & 1.2 & 0.5 \\
\hline \multirow{2}{*}{ T-9 } & 324 & 0.82 & 0.28 & 2.7 & 1.2 & 0.4 & 2.3 & 1.3 & 0.7 \\
\hline & 3238 & 2.53 & 0.30 & 4.4 & 1.7 & 0.6 & 5.9 & 1.5 & 1.0 \\
\hline \multirow{2}{*}{$T-10$} & 3238 & 3.12 & 0.42 & 4.3 & 1.7 & 0.6 & 6.1 & 1.7 & 1.1 \\
\hline & 3238 & 2.96 & 0.52 & 4.5 & 1.9 & 0.6 & 6.4 & 1.7 & 1.1 \\
\hline
\end{tabular}

* B expressed as $\mu \mathrm{mol} /$ litre, the other elements as $\mathrm{mmol} / \mathrm{litre}$.

Total root weight was significantly reduced only when one or both compartments contained $3238 \mu \mathrm{mol} \mathrm{B} /$ litre (Table 1). Root weight was little affected by absence of boron in one or both parts of the system. However, the shape of the root system of plants showing B deficiency symptoms in the aerial parts was round instead of oblong. Evidently B deficiency affected root elongation. This is in agreement with the findings reported by Kouchi \& Kumazawa (1976).

The data from Table 2 show that the roots without boron in their medium took up less phosphorus and potassium. This fact, in combination with the lower $P$ concentration in the leaf tissue, may indicate decreased root activity, especially since root weight was not decreased.

Boron concentrations of $3238 \mu \mathrm{mol}$ in the root medium resulted in high concentrations of most of the nutrients in the solution. This may be due to an effect of boron per se, to reduced top growth, or both. The data in Table 2 also show that some translocation of boron took place from high-B roots to low-B roots, since the $B$ values found in the compartments containing the zero-B concentration were always higher than those in the stock solution. Eaton (1941) observed a similar movement of chloride through the roots into the solution that initially 
contained a trace of chloride. In an earlier publication, the authors (Cerdá \& Roorda van Eysinga, 1981) reported an indication of such a movement of nutrients through the roots of tomato grown on rock-wool in a split-root system.

\section{Differential B uptake}

Table 3 shows the average B content of leaf, top, and root in relation to the B level supplied to each part of the root system. Concentrations of all nutrients are not reported; they were not affected by the treatments, except the $\mathrm{P}$ and $\mathrm{K}$ contents of the leaves, which increased from 0.25 to $0.38 \mathrm{~mol} P$ and from 1.13 to 1.54 mol $\mathrm{K}$ per $\mathrm{kg}$ dry matter when the $\mathrm{B}$ level in both parts of the system increased from 0 to $3238 \mu \mathrm{mol} \mathrm{B} /$ litre.

Boron contents in the plant material increased with increasing $B$ levels in one or both parts of the system. Boron concentrations in the leaves were consistently higher than those in other parts of the plant. Boron contents of the roots were 2-3 times lower than those of the leaves, while the B concentrations of the tops were about half as high. Boron concentrations in shoots and fruits were also lower than those in leaves. Eaton (1944) attributed this high accumulation of boron in the leaves to the fact there is little re-movement of boron after it has been carried

Table 3. Boron content of the leaves, tops and roots of tomato plants in relation to the B concentration in each half of the root system.

\begin{tabular}{|c|c|c|c|c|}
\hline \multicolumn{2}{|c|}{ Treatment } & \multicolumn{3}{|c|}{ B concentrations ( $\mathrm{mmol} / \mathrm{kg}$ dry matter) } \\
\hline Code & $\begin{array}{l}\text { B level in each } \\
\text { half of the root } \\
\text { system ( } \mu \mathrm{mol} / \text { litre })\end{array}$ & leaves & tops & roots \\
\hline \multirow{2}{*}{$\mathrm{T}-1$} & 0 & 2.1 & \multirow{2}{*}{2.3} & 1.7 \\
\hline & 0 & 1.8 & & 1.8 \\
\hline \multirow{2}{*}{$\mathrm{T}-2$} & 0 & 3.8 & \multirow{2}{*}{3.0} & 2.0 \\
\hline & 32 & 5.2 & & 2.4 \\
\hline \multirow{2}{*}{ T-3 } & 0 & 8.7 & \multirow{2}{*}{6.4} & 2.7 \\
\hline & 324 & 14.7 & & 5.6 \\
\hline \multirow{2}{*}{$\mathrm{T}-4$} & 0 & 59.0 & \multirow{2}{*}{42.5} & 12.2 \\
\hline & 3238 & 95.6 & & 37.1 \\
\hline \multirow{2}{*}{$\mathrm{T}-5$} & 32 & 5.9 & \multirow{2}{*}{3.6} & 2.8 \\
\hline & 32 & 6.2 & & 2.8 \\
\hline \multirow{2}{*}{ T.6 } & 32 & 11.5 & \multirow{2}{*}{6.9} & 4.2 \\
\hline & 324 & 15.2 & & 6.3 \\
\hline \multirow{2}{*}{$\mathrm{T}-7$} & 32 & 78.4 & \multirow{2}{*}{48.7} & 17.4 \\
\hline & 3238 & 91.1 & & 31.5 \\
\hline \multirow{2}{*}{$\mathrm{T}-8$} & 324 & 22.3 & \multirow{2}{*}{15.5} & 8.9 \\
\hline & 324 & 27.8 & & 17.5 \\
\hline \multirow{2}{*}{ T-9 } & 324 & 65.4 & \multirow{2}{*}{44.0} & 19.9 \\
\hline & 3238 & 110.6 & & 50.2 \\
\hline \multirow{2}{*}{$\mathrm{T}-10$} & 3238 & 139.4 & \multirow{2}{*}{71.5} & 50.5 \\
\hline & 3238 & 145.3 & & 38.2 \\
\hline
\end{tabular}


into the leaves in the transpiration stream. This is supported by the data of this experiment, because when the solutions in the two halves of the system contained different amounts of boron, the B concentration was always greater in the leaves on the high-B side than in the leaves on the low-B side. The B content of the leaves on the low-B side increased as the $B$ content of the leaves on the high$B$ side increased (compare, for example, the B content of the leaves of T-1 and that of the leaves of the $0-B$ side of the treatments T-2, T-3 and T-4). These observations seem to indicate that there is lateral movement of boron from the high-B to the low-B side of the plant as well as vertical movement with the transpiration stream. By lateral movement the $B$ requirement for normal growth of all plant parts appears to be met; boron may even accumulate to toxic levels when it is supplied at high concentrations. Two processes may increase the B content of the leaves on the side supplied with a 0-B solution, viz (1) a direct transport of boron from high-B roots to low-B roots through the lower stem and a subsequent transport to low-B leaves, and (2) lateral movement inside the plant from high-B leaves to low-B leaves.

The second point is in agreement with observations of Oertli \& Richardson (1970) in cotton. They found that boron, at least when present in excessive amounts, readily moves longitudinally in both directions in the bark and also laterally between bark and wood. In split-root experiments with sunflower, Husa \& McIlrath (1965) found that when boron is administrated in a limited amount to only a part of the root system little lateral transport occurs to sinks supplied by vascular elements from other roots. On the other hand, if a part of the root system absorbs boron in excess of the metabolic requirements of tissues normally supplied by such roots, lateral movement of boron will take place in the lower portions of the stem to fill the metabolic requirements of the other parts of the plant.

In our experiment, half the root system growing in a solution containing 32 $\mu \mathrm{mol} \mathrm{B} /$ litre was able to supply the B requirement of the whole plant, which showed no deficiency symptoms during the experimental period. It may be concluded that B levels of 32 to $324 \mu \mathrm{mol} /$ litre applied in one or both root compartiments were adequate for normal plant growth (see treatments T-2, T-3, T-5, T-6, and T-8). B contents in the leaves, ranging from 4 to $28 \mathrm{mmol} / \mathrm{kg}$ were sufficient, since yields remained near-optimum within that range. A B content of 2 $\mathrm{mmol} / \mathrm{kg}$ was accompanied by deficiency symptoms and reduced yields. Leaf $\mathrm{B}$ contents higher than $28 \mathrm{mmol} / \mathrm{kg}$ were toxic. The optimum range found here (4$28 \mathrm{mmol} \mathrm{B} / \mathrm{kg}$ ) is wider than that given by Roorda van Eysinga \& Smilde (1981). This discrepancy may be explained by the fact that the weight of tops was not affected by a light excess of boron. In treatment $T-8$, for example, the leaves had a high B content and showed mild toxicity symptoms, but fresh and dry weights of tops were high. 


\section{References}

Bingham, F. T. \& M. J. Garber, 1970. Zonal salinization of the root system with $\mathrm{NaCl}$ and boron in relation to growth and water uptake of corn plants. Soil Sci. Soc. Am. Proc. 34: 122-126.

Cerdá. A. \& J. P. N. L. Roorda van Eysinga, 1981. Tomato plant growth as affected by horizontally unequal osmotic concentrations in rock-wool. Neth. J. agric. Sci. 29: 189-197.

Eaton, F. M., 1941. Water uptake and root growth as influenced by inequalities in the concentration of the substrate. Plant Physiol. 16: 545-564.

Eaton, F. M., 1944. Deficiency, toxicity and accumulation of boron in plants. J. agric. Res. 69: 237 277.

Gupta, U. C., 1979. Boron nutrition of crops. Adv. Agron. 31: 273-307.

Husa, J. G. \& W. J. McIlrath, 1965. Absorption and translocation of boron by sunflower plants. Bot. Gaz. 126: 186-194.

Kouchi, H. \& K. Kamuzawa, 1976. Anatomical response of root tips to boron deficiency. I. Effects of boron deficiency on elongation of root tips and their morphological characteristics. Soil Sci. Plant Nutr. 21: 21-28.

Maynard, D. N., B. Gersten \& L. F. Michelson, 1959. The effects of boron nutrition on the occurrence of certain tomato fruit disorders. Proc. Am. Soc. hort. Sci. 74: 500-505.

Oertli. J. J. \& W. F. Richardson, 1970. The mechanism of boron immobility in plants. Phisiologia Pl. 23: $108-116$.

Reisenauer. H. M.. L. M. Walsh \& R. G. Hoeft, 1973, In: L. M. Walsh \& J. D. Beaton (Eds). Soil testing and plant analysis. Soil Science Society of America, Madison, Wisconsin. pp. 173-200.

Roorda van Eysinga, J. P. N. L. \& K. W. Smilde, 1981. Nutritional disorders in glasshouse tomatoes. cucumbers and lettuce. Pudoc. Wageningen. $130 \mathrm{pp}$.

Spurr, A. R.. 1957. The effect of boron on cell-wall structure in celery. Am. J. Bot. 44: 637-650. 